MINERALOGIA, 40, No. 1-4: 43-52 (2009)

DOI: $10.2478 / v 10002-009-0001-4$

www.Mineralogia.pl

MINERALOGICAL SOCIETY OF POLAND

POLSKIE TOWARZYSTWO MINERALOGICZNE

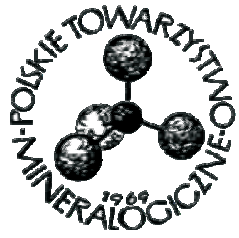

Original paper

\title{
Sorption of light hydrocarbons on clays from the Oligocene Kiscell Clay Formation, Hungary
}

Judit TÓTH ${ }^{1}$

${ }^{1}$ MOL Plc. Exploration and Production Division, Integrated Field Application, New Technologies and R\&D, Applied Technologies and Development, Batthyány str. 45, H-1039 Budapest, Hungary;

e-mail: judittoth@mol.hu

Received: March 28, 2009

Received in revised form: August 19, 2009

Accepted: August 31, 2009

Available online: November 20, 2009

\begin{abstract}
Clays from Solymár (Hungary) were treated with volatile components of light hydrocarbon in order to investigate their ability to sorb these organic compounds. The clays were characterized using XRD, optical microscopy (thin sections) and CEC measurements. The contaminated samples were analyzed using ATD-GC-MS, Rock Eval and XRD. Volatilization of the fluid phase hydrocarbon was monitoring for 663 days. The quantity of volatilized hydrocarbon compounds reached $50.0-65.0 \%$ at the end of the experiment. All of the analyses indicate hydrocarbon pollution of the clay layers after the volatilization process. The gross compositions of the fluid and the sorbed phases are different; the total amount of cycloalkanes among the sorbed hydrocarbons is very low. The dominant sorbed components are toluene, xylenes, $n \mathrm{C}_{9}, n \mathrm{C}_{10}, n \mathrm{C}_{11}$ and $n \mathrm{C}_{7}$. Cyclohexane, methylcyclohexane, benzene, $n \mathrm{C}_{12}$ and $n \mathrm{C}_{13}$ also occur in lower concentrations. The geochemical and XRD results indicate that adsorption onto the external surfaces of the clay minerals was the main sorption process.
\end{abstract}

Key-words: light hydrocarbon, sorption of hydrocarbon, contamination, clay

\section{Introduction}

Petroleum contamination in the environment spreads by migration in solution in surface- or subsurface waters and as liquid hydrocarbons. During the migration, various natural attenuation processes occur. Some of these can significantly modify the concentration and composition of the contamination.

Hydrocarbon components can be sorbed onto the constituents of soils from both dissolved phases and from liquid hydrocarbons. Among the soil constituents, clay minerals, carbonates, 
Fe and Mn oxides/hydroxides and organic materials (e.g., humic substances) have significant sorption capacities.

Most sorption researches have involved studies of individual hydrocarbon components on minerals (e.g., Madsen et al. 1996; Goss 1993; Daqing et al. 2006), on organic materials or on organoclays (e.g., Slabaugh, Vasofsky 1975; Wolfe et al. 1985, Jaynes, Boyd 1991; Sheng, Boyd 2000). Only a few have involved multicomponental hydrocarbons as contaminants (e.g., Yaron et al. 1989; Cheng, Huang 2004). Studies investigating sorption on dry or low relative humidity soils are rare (e.g., Poe et al. 1988). Moreover, the sorption properties of volatilized hydrocarbons have not been investigated in detail up to now.

Because of the lack of studies involving volatilized hydrocarbons, a special laboratory modeling was conducted for 663 days. The objective was to investigate the volatilization and sorption features of a hydrocarbon mixture. The hydrocarbon sorption properties were examined on dry sands and clays.

\section{Materials and methods}

Clay samples were collected from the pit of the Wienerberger brickyard in Solymár near Budapest. In the pit, the Kiscell Clay Formation occurs as the main Oligocene lithological unit - a unit that is widespread in Hungary. The clay mineral fraction comprises smectite (27 $\mathrm{wt} \%)$, muscovite (36 wt\%), mixed-layer clay minerals. i.e., illite/chlorite and kaolinite/ /chlorite (37 wt\%). Quartz, calcite, dolomite and feldspars can also be recognized by X-ray diffraction (XRD). Further information on the mineralogy of the clays is given by, for example, Báldi (1998) and Kalmár et al. (2003). The cation exchange capacity (CEC-value) of the sample, measured using Mehlich's method, is 33.16 meq/100 g (Tóth, Knapp 2007).

A laboratory model was constructed to investigate the hydrocarbon volatilization and sorption properties. Details of the laboratory model used have been described elsewhere (Tóth, Török 2006). In brief, the model comprised eight special glass columns of four different heights (from $50 \mathrm{~cm}$ to $200 \mathrm{~cm}$ ) and filled with different filling materials in pairs. The construction of the columns enabled the sorption features of the volatilized hydrocarbon components to be measured on dry sand and clay. Freshly-collected clay from the Kiscell Clay Formation, commercial sand and a liquid hydrocarbon mixture were used in the long-term experiment. The resulting data on hydrocarbon sorption on the clay are presented here.

Initially, samples of the liquid gasoline were taken weekly, later monthly. Filling materials of the top layers and the free gases were sampled after six and twelve months. After 640 days, every column was sampled layer-by-layer for sorbed and free hydrocarbons (90 sampling points in total). Samples were analyzed immediately. Subsamples were stored in a refrigerator to minimize evaporation of volatile hydrocarbons before control analyses.

The composition of the fluid phase was analyzed by GC-FID (gas chromatograph-flame ionization detector). The detailed composition of the sorbed hydrocarbons was monitored by ATD-GC/MS (automatic thermodesorption-gas chromatograph/mass spectrometer). Details of the applied GC-FID and ATD-GC/MS methods are published elsewhere (Tóth, Török 2006; Tóth, Knapp 2007). In brief, the ATD-GC/MS analyses were performed with a Gerstel TDS A2 autosampling system, a Gerstel TDS 3 heating system, and a CIS 4 (Cooled Injection System) 
with an Agilent 6890N Gas Chromatograph interfaced to an Agilent 5973 Mass Selective Detector. The technical parameters were as follows: Gerstel TDS oven programmed from $60^{\circ} \mathrm{C}$ (isothermal for $0 \mathrm{~min}$ ) with a $60^{\circ} \mathrm{C} / \mathrm{min}$ ramp rate to $310^{\circ} \mathrm{C}$ (isothermal for $10 \mathrm{~min}$ ), transfer temperature of $300^{\circ} \mathrm{C}$, CIS 4 liquid $\mathrm{N}_{2}$ cooling, Carbotrap B adsorbent bed, oven programmed from $-20^{\circ} \mathrm{C}$ with a $12^{\circ} \mathrm{C} / \mathrm{min}$ heat up rate to $300^{\circ} \mathrm{C}$ (isothermal for $10 \mathrm{~min}$ ). The gas chromatograph part was operated as follows: CIS split ratio set to $20: 1$, He as carrier gas, HP-PONA column $(50 \mathrm{~m}$ length, $0.20 \mathrm{~mm}$ internal diameter, $0.50 \mu \mathrm{m}$ film thickness, $100 \%$ dimethyl-siloxane) or HP-1MS column (30 m length, $0.32 \mathrm{~mm}$ internal diameter, $1 \mu \mathrm{m}$ film thickness, $100 \%$ dimethyl-siloxane). The gas chromatograph oven was programmed from $40^{\circ} \mathrm{C}$ (isothermal for $4 \mathrm{~min}$ ) with $10^{\circ} \mathrm{C} / \mathrm{min}$ ramp rate to $170^{\circ} \mathrm{C}$ (isothermal for $10 \mathrm{~min}$ ), and from $170^{\circ} \mathrm{C}$ with a $20^{\circ} \mathrm{C} / \mathrm{min}$ ramp rate to $300^{\circ} \mathrm{C}$ (isothermal for $15 \mathrm{~min}$ ). The sorption properties of the clay were also investigated by pyrolysis using a Rock Eval 6 apparatus. The clays were not prepared in any special way for modeling and analyses. The mineralogical compositions and alterations of the samples were determined by X-ray diffraction using a Philips 1820 type diffractometer. The technical parameters of the XRD measurements were: $\mathrm{Cu}$ tube anode, start angle of $2^{\circ} 2 \Theta$, end angle of $70^{\circ} 2 \Theta$ and/or end angle of $30^{\circ} 2 \Theta$.

\section{Results and discussion}

The model was able to simultaneously treat the transport of the volatilized compounds involved in this investigation of sorption processes. It also enabled the modeling of the altering concentrations in the different unsaturated media. The volatilization of the fluid hydrocarbon was monitored for 663 days. The GC/FID chromatogram of the fresh fluid gasoline is characterized by a falling series of normal alkanes, isoalkanes and aromatic compounds, and by relatively high quantities of gasoline range hydrocarbons (Fig. 1).

The liquid gasoline used for the modeling initially consisted of compounds ranging up to $\mathrm{C}_{19}$. Heavier hydrocarbons were enriched in the liquid phase due to volatilization of hydrocarbons of lower carbon number. Depending on the mineral composition of the geological samples, $6.6-11.6 \%$ of the initial quantity of liquid hydrocarbon volatilized during the first three weeks. After half a year and after one year, $27.7-37.2 \%$ and $37.7-51.1 \%$ of the liquid fraction had volatilized, respectively. The proportion of volatilized hydrocarbon compounds reached $50.0-65.0 \%$ at the end of the experiment (Tóth 2008).

Chromatograms of the fresh and degraded samples are significantly different, due to the intensive volatilization. The highly degraded samples were in the bottoms of columns with small heights, and preferably with a pure sand filling. The loss of gasoline range components was significant in the non-volatilized residues. For example, in the case of $50 \mathrm{~cm}$ clay-capped tubes, the total quantity of gasoline range compounds decreased from $65.65 \mathrm{~mol} \%$ to $43.65 \mathrm{~mol} \%$ by the end of the experiment. The total volatilization losses indicate that a significant amount of light- and medium molecular weight hydrocarbon can be sorbed on the clay.

The compositions of the fluid- and the sorbed phases are different (Fig. 2). The total abundance of cycloalkanes among the sorbed hydrocarbons is very low. In Figure 2, the amounts of fluid phase remaining after different modeling times are plotted; the significant overlap indicates that volatilization had slightly altered the gross composition of the gasoline. 


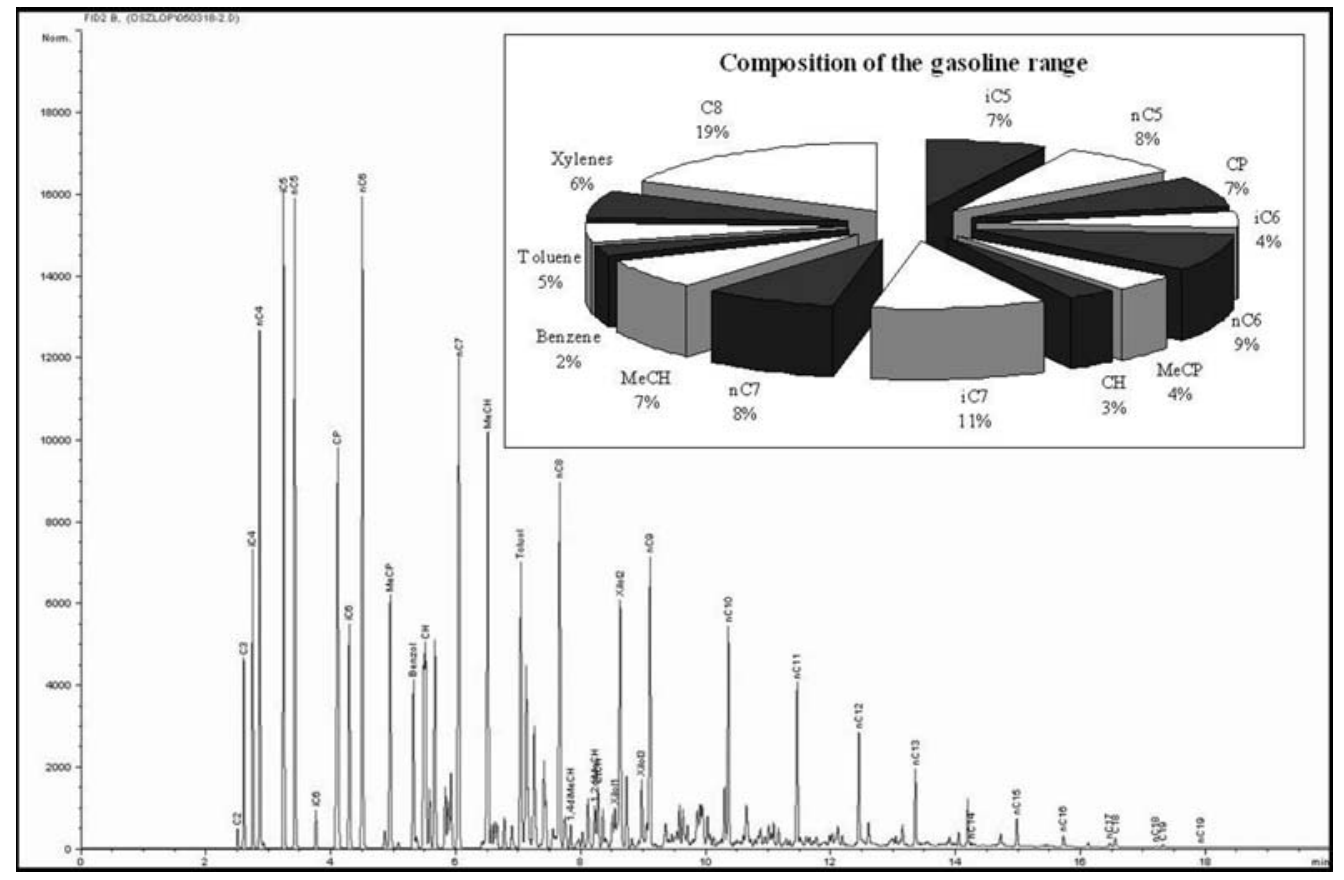

Fig. 1. Gas chromatogram of the total hydrocarbon fraction of the fresh fluid phase and the initial percentage of the gasoline range components

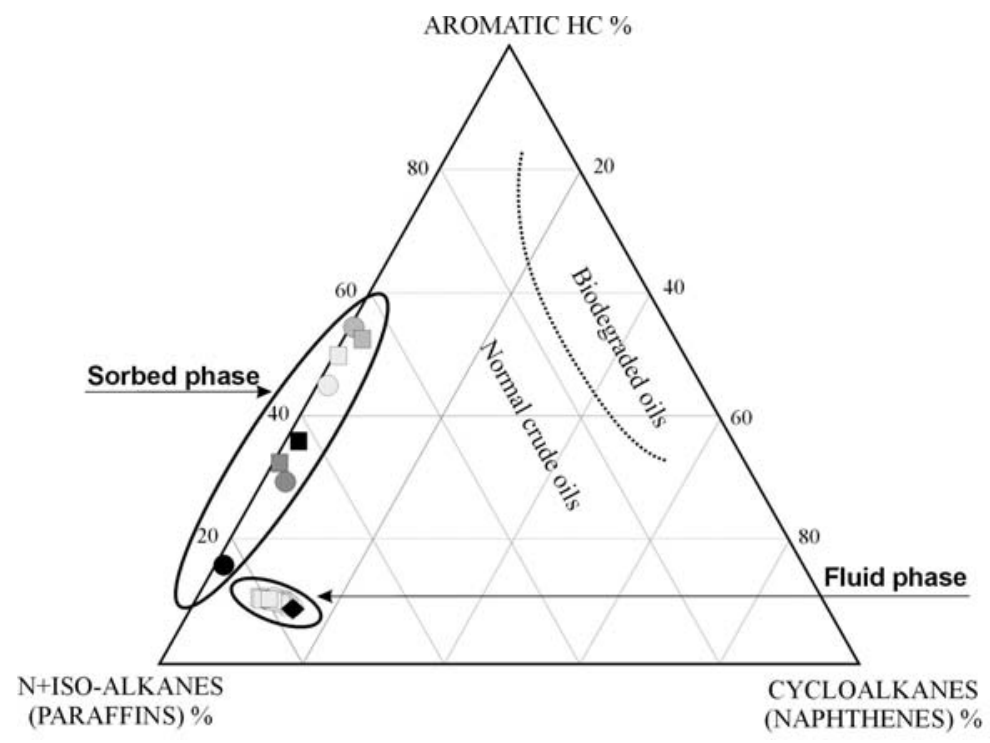

Fig. 2. Ternary diagram of the fluid and sorbed phase composition.

The dashed line represents the border among normal crude oils and biodegraded oils. Initial composition - black rhombus. Weathered gasoline samples - grey symbols. Uppermost clay layers with sorbed hydrocarbons - squares.

Deeper clay layers with sorbed hydrocarbons - circles. Colours darken with increasing column height 
Based on the ternary diagram (Fig. 2), it can be concluded that volatilization has only a very minor effect on the proportion of aromatic components and a greater effect on that of cycloalkanes. After contamination by volatilized hydrocarbons for 663 days, depletion of cycloalkanes and enrichment of aromatic hydrocarbons can be observed in the clay-sorbed hydrocarbons when compared to those in the fluid phase. A significant difference can also be recognized in the distribution of paraffins. While variation in the paraffin contents of the fluid samples is relatively low, variation in those sorbed on the clays is marked.

Using the $100 \mathrm{~cm}$ column as an example, the vertical distribution of the sorbed hydrocarbon compounds with depth is shown in Figure 3. The hydrocarbons are clearly enriched in the upper part of the column. This demonstrates the higher hydrocarbon sorption capacity of clay compared to sand as the clay constituted a thick $(8 \mathrm{~cm})$ cap-layer on the top of the sand-filled columns.

As the plant debris and organisms are good adsorbents of organic micro-pollutants and heavy metals, the total organic content should be determined (Kralik 1999). The total organic carbon (TOC) value can be converted to the total organic matter (TOM) value by multiplying TOC by approximately 1.2 . However, in geochemical reports, the TOC value is typically used. TOC values for the clays from the Kiscell Clay Formation range from $0.33-0.41 \%$. Presumably, it is due to the hydrocarbon contamination that this TOC value is slightly higher than those for different types of clays reported in the literature. For example clays from the NW border of the Polish Holy Cross Mts are characterized by a very low (0.05-0.14 wt\%) TOC content (Marynowski et al. 2006) though some clay layers show much higher values. In comparison to other regions, clays from the Polish Lowland are generally enriched in organic carbon (Marynowski et al. 2007). The majority of the samples of Triassic clays from the Upper Silesian Basin and the NW border of the Holy Cross Mts have low TOC contents ranging from $0.02-0.53 \%$; only green clays from the lower part of the Lipie section reveal much higher values ranging from 1.45-2.30\% (Marynowski, Wyszomirski 2008). Other bulk parameters provided by Rock Eval analyses (e.g., higher S1, S2, $\mathrm{HC}$ potential) confirm the hydrocarbon pollution of our clay samples.

A comparison of the GC peak areas of the clay samples is shown in Figure 4. The analytical results indicate that most of the common gasoline range and some slightly heavier compounds were present in the sorbed phase after 640 days.

The dominant components are toluene, xylenes, $n \mathrm{C}_{9}, n \mathrm{C}_{10}, n \mathrm{C}_{11}$ and $n \mathrm{C}_{7}$. Cyclohexane, methylcyclohexane, benzene, $n \mathrm{C}_{12}$ and $n \mathrm{C}_{13}$ also occur in lower concentrations (Fig. 5).

The chromatograms of the clays show an $n$-alkane distribution with a maximum for toluene to $\mathrm{C}_{9}$. The lighter hydrocarbons are essentially missing due to volatilization but can be measured by free gas analyses. Clay layers which were in contact with air contain less measurable hydrocarbons than do deeper ones. This can be due to the sealing effect of the uppermost layer.

Cheng and Huang (2004) presented experimental data on the adsorption selectivity of hydrocarbon gases on clays and organic matter in a simple system. The $\mathrm{C}_{2}-\mathrm{C}_{6}$ gases were selectively more strongly adsorbed than the heavier gas molecules what confirmed that the selectivity resulted mainly from the variations in their vapor pressures. Results from the modeling are consistent with this though measurable compounds below $\mathrm{C}_{6}$ are very low in comparison to heavier compounds.

Among BTX (benzene, toluene and xylenes) compounds, the quantity of sorbed benzene is very small. Though vapor pressure values and Henry's Law constants would suggest similar 


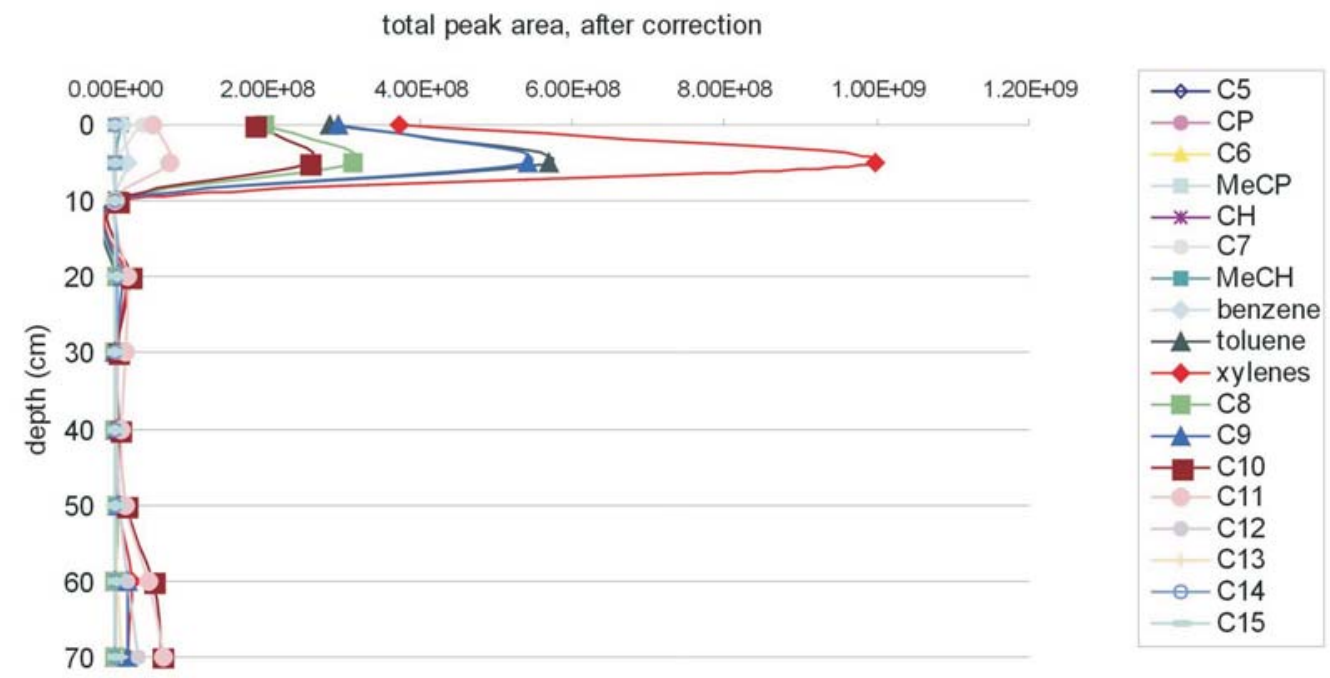

Fig. 3. Vertical distribution of hydrocarbon compounds with depth

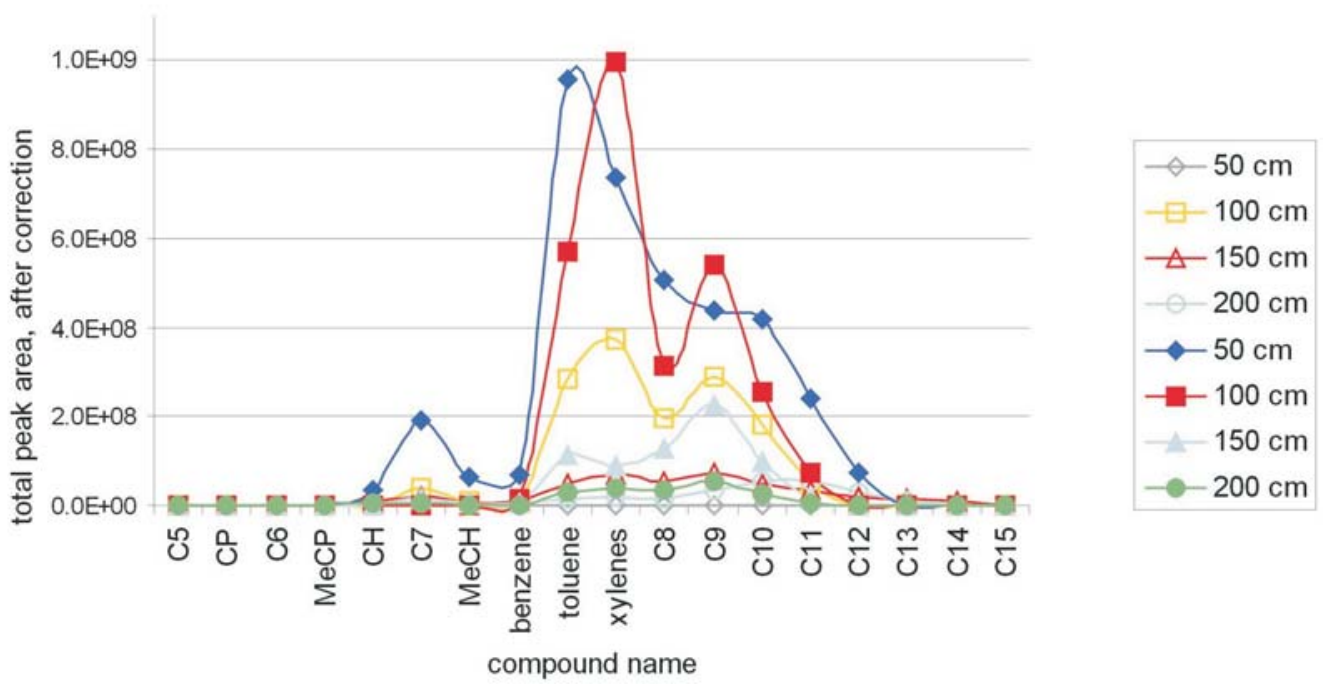

Fig. 4. Comparison of the GC peak areas of the investigated clay samples. Open symbols represent the upper clay layers, filled symbols the lower clay layers

volatilities for BTX, these components in fact show significant deviations. Benzene has the highest volatilization rate among BTX and the lowest sorption affinity for clay minerals. Namkoong et al. (2003) demonstrated that BTEX (benzene, toluene, ethylbenzene and xylenes) displayed a similar tendency during biofilter operations. In their opinion, the lowest removal efficiency of benzene among BTEX by biofiltration may have been due to its high toxicity.

The dominant type of sorption interaction in the modeling experiment was also determined by XRD. Most previous studies involve organoclays; only some investigated natural clays or 


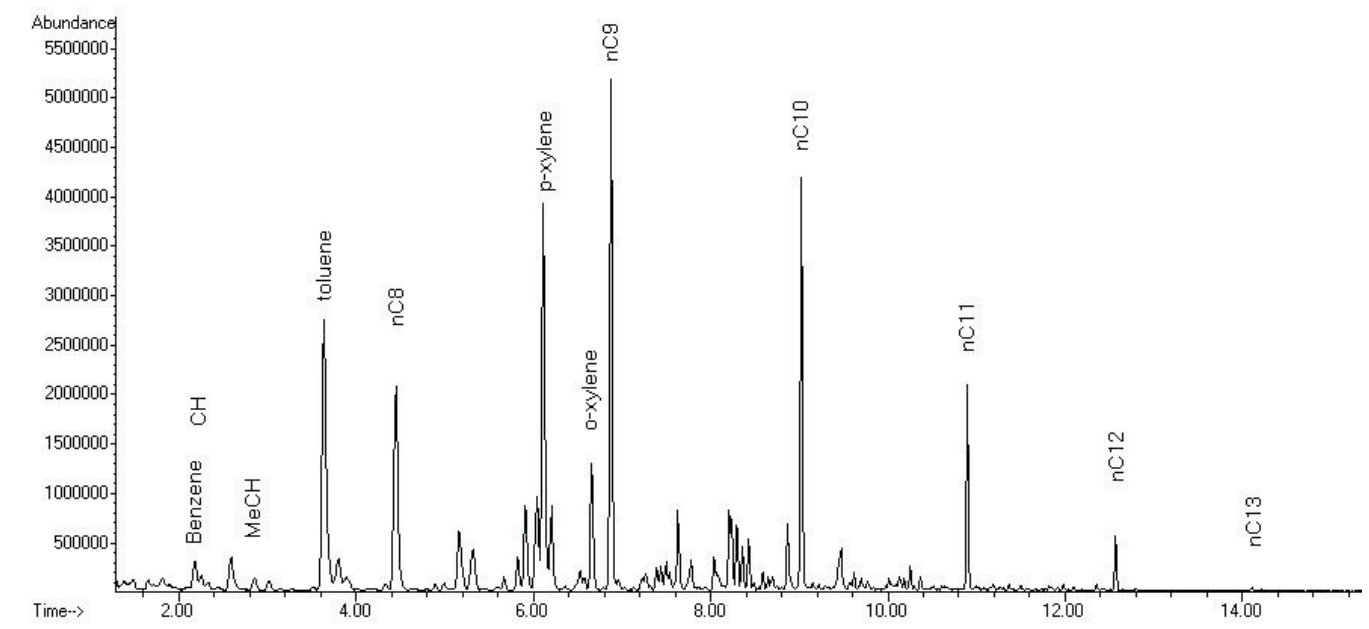

Fig. 5. Gas chromatogram of the sorbed hydrocarbon fraction after 640 days

provide a basis for comparison between natural and modified clays. (Organoclays are high organic-affinity clays synthesized by ion exchange of quaternary ammonium organic cations onto the clay-mineral surfaces). Gitipour et al. (2006) reported that organobentonites effectively intercalate gasoline hydrocarbons into the clay particles. In this case, the particle thickness of the modified bentonite increased from 27.07 to $39.11 \AA$, whereas XRD analysis of the natural bentonite showed only a slight increase from 12.44 to $13.38 \AA$. Other studies have also shown that, only in the case of organoclays, is there any significant basal-distance change due to

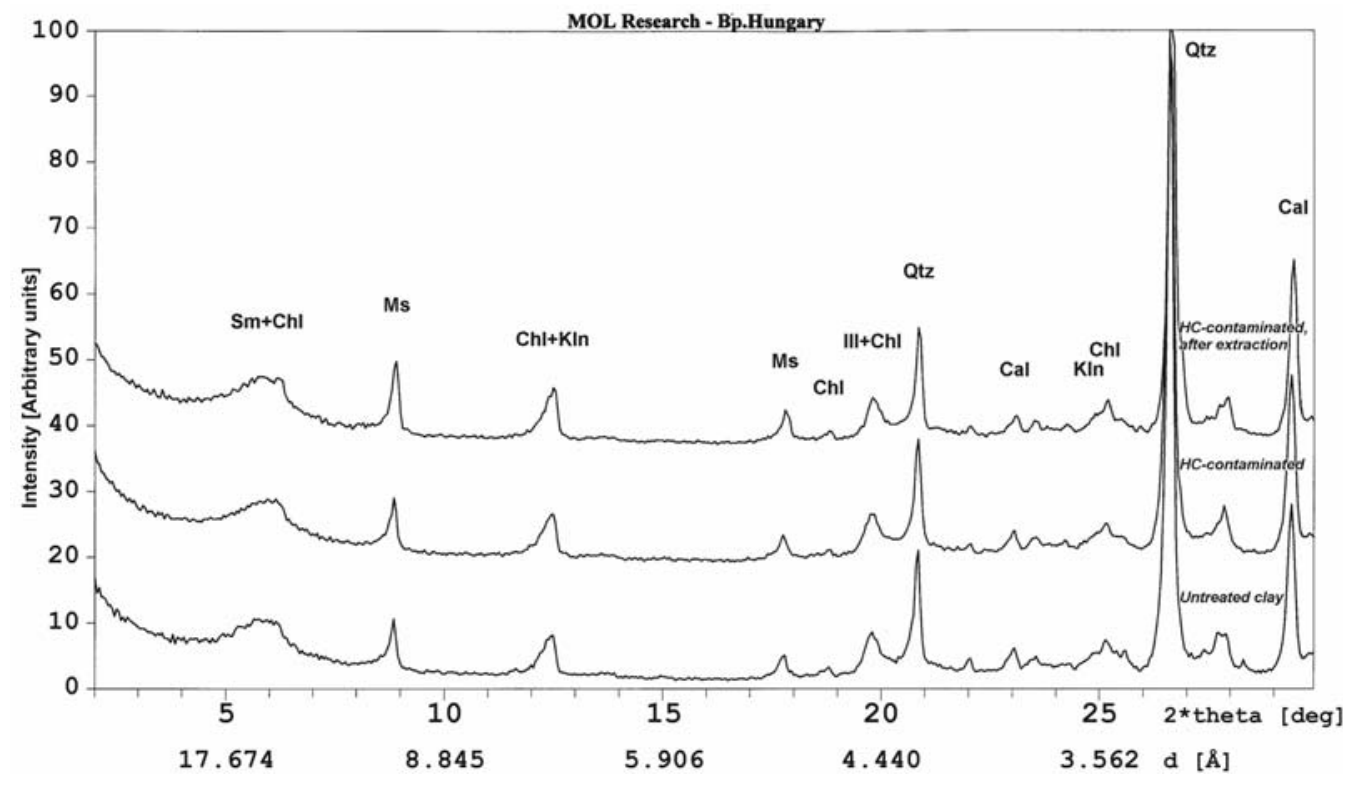

Fig. 6. Diffractograms of the investigated clays 
contamination with hydrocarbon mixtures. However, some provide evidence of interlayered organic molecules - mainly smaller organic compounds (e.g. Eltantwy, Arnold 1972; Velde 1992). The study reported here reveals no measurable difference between the X-Ray patterns of the untreated-, contaminated- and extracted samples of the clays investigated (Fig. 6).

Basal spacings ( $\mathrm{d}_{001}$-values) for the clay minerals of the untreated- and polluted clays are nearly identical, indicating that adsorption on the external mineral surfaces was the main sorption process. No insertion into the swelling clay minerals can be observed. The results of the modeling confirm the conceptions of Sawhney (1985) and Rhue et al. (1988) who also investigated vapor-phase adsorption.

\section{CONCLUSIONS}

The ATD-GC/MS method presented is rapid, convenient, efficient and suitable for the detailed analysis of sorbed light hydrocarbons in dry soil samples. The analysis of sorbed phases can be a good tool in site investigations, but it has limiting factors pertaining to, e.g., smectite quantities and relative moisture contents, when thermodesorption is applied. Rock Eval pyrolysis and X-Ray diffraction can give useful information on sorption process. XRD patterns determined before and after contamination, and complemented with extracted samples, can aid understanding of the character of a given hydrocarbon pollution, and of the relevant soil characters.

Acknowledgments. The author thanks Dr. Endre Balázs, László Győry, Zsolt Molnár and Tibor Ördög, MOL Group Managers, for the opportunity to carry out the research and publish the results. I wish also to thank to Dr. Tibor Szederkényi (University of Pécs), Dr. Andrea Szuromi-Korecz and Andrea Lukács (MOL Group) for significant consultations. The help provided by Erika Szabóki-Knapp, Irén Pap-Hasznos and Dr. Éva Váradi (MOL Plc, EPTOC) during analysis is appreciated. The paper has been greatly improved by the critical comments and constructive suggestions of two anonymous reviewers.

\section{References}

Báldi T. (1998). Magyarország epikontinentális oligocén képződményeinek rétegtana. In I. Bérczi \& Á. Jámbor (Eds.), Magyarország geológiai képzödményeinek rétegtana (pp. 419-436). Budapest: MOL Hun. Oil and Gas Comp. and Geol. Inst. Hun., Plc.- MÁFI, (in Hungarian).

Cheng A-L. \& Huang W.L. (2004). Selective adsorption of hydrocarbon gases on clays and organic matter. Organic Geochemistry, 35(4), 413-423.

Daqing W., Guiyi D., Peng Y. \& Jinlian P. (2006). Adsorption of Pentachlorophenol onto Oxide and Clay Minerals: Surface Reaction Model and Environmental Implications. Acta Geologica Sinica, Journal of the Geological Society of China, 80(2), 192-199.

Eltantwy I.M. \& Arnold P.W. (1972). Adsorption of n-alkanes on Wyoming montmorillonite. Nature Physical Science, 237, 123-125.

Gitipour S., Baghvand A. \& Givehchi S. (2006). Adsorption and Permeability of Contaminated Clay Soils to Hydrocarbons. Pakistan Journal of Biological Sciences, 9(3), 336-340. 
Goss K.U. (1993). Effects of Temperature and Relative Humidity on the Sorption of Organic Vapors on Clay Minerals. Environmental Science \& Technology, 27(10), 2127-2132.

Jaynes W.F. \& Boyd S.A. (1991). Clay Mineral Type and Organic Compound Sorption by Hexadecyltrimethlyammonium-Exchanged Clays. Soil Science Society of America Journal, 55(1), 43-48.

Kalmár J., Szurkos G. \& Kovács-Pálffy P. (2003). Üledékképzödés és kőzettéválás a dél-budai Kiscelli Agyag Formációban, a IV. sz. metró nyomvonalán mélyült fúrásokban (Sedimentation and lithification in the Kiscell Clay Formation from South Buda, in the boreholes deepened in the pathway of the (projected) IVth Metro Line). MÁFI Évi Jelentése, 2000-2001 (Annual Report of the Hungarian Geological Institute of 2000-2001), 107-119 (in Hungarian).

Kralik M. (1999). A rapid procedure for environmental sampling and evaluation of polluted sediments. Applied Geochemistry, 14(6), 807-816.

Madsen L., Grahl-Madsen L., Grřn C., Lind I. \& Engell J. (1996). Adsorption of polar aromatic hydrocarbons on synthetic calcite. Organic Geochemistry, 24(12), 1151-1155.

Marynowski L., Wyszomirski P. \& Kurkiewicz S. (2006). The characteristics of organic matter from the triassic clays of NW margin of the Holy Cross Mts. (Poland) - Preliminary report. Mineralogia Polonica, 37(2), 117-125.

Marynowski L., Zaton M., Simoneit B.R.T., Otto A., Jedrysek M.O., Grelowski C. \& Kurkiewicz S. (2007). Compositions, sources and depositional environments of organic matter from the Middle Jurassic clays of Poland. Applied Geochemistry ,22(11), 2456-2485.

Marynowski L. \& Wyszomirski P. (2008). Organic geochemical evidences of early-diagenetic oxidation of the terrestrial organic matter during the Triassic arid and semi arid climatic conditions. Applied Geochemistry, 23(9), 2612-2618.

Namkoong W., Park J.-S. \& VanderGheynst J.S. (2003). Biofiltration of gasoline vapor by compost media. Environmental Pollution, 121(2), 181-187.

Poe S.H., Valsaraj K.T., Thibodeaux L.J. \& Springer C. (1988). Equilibrium vapor phase adsorption of volatile organic chemicals on dry soils. Journal of Hazardous Materials, 19(1), 17-32.

Rhue R.D., Rao P.S.C. \& Smith R. . (1988). Vapor-phase adsorption of alkylbenzenes and water on soils and clays. Chemosphere, 17(4), 727-741.

Sawhney B.L. (1985). Vapor-phase sorption and polymerization of phenols by smectite in air and nitrogen. Clays and Clay Minerals, 33(2), 123-127.

Sheng G. \& Boyd S.A. (2000). Polarity Effect on Dichlorobenzene Sorption by Hexadecyltrimethylammonium-Exchanged Clays. Clays and Clay Minerals ,48(1), 43-50.

Slabaugh W.H. \& Vasofsky R.W. (1975). Adsorption of xylene by organoclays. Clays and Clay Minerals, 23(6), $458-461$.

Tóth, J. (2008). Sorption of the volatile hydrocarbons compounds by Oligocene clay. Mineralogia - Special Papers, 32 , 162.

Tóth J. \& Knapp E. (2007). Sorption properties of light hydrocarbon contaminated clay under defined condition. Central European Geology ,50(1), 79-94.

Tóth J. \& Török E. (2006). Geochemistry-based modeling of hydrocarbon contamination. European Geologist ,22, $32-35$.

Velde B. (1992). Introduction to Clay Minerals. Chemistry, origins, uses and environmental significance. London, New York: Chapman \& Hall.

Wolfe T.A., Demirel T. \& Baumann E.R. (1985). Interaction of Aliphatic Amines with Montmorillonite to Enhance Adsorption of Organic Pollutant. Clays and Clay Minerals, 33(4), 301-311.

Yaron B., Sutherland P., Galin T. \& Acher A.J. (1989). Soil pollution by petroleum products, II. Adsorption-desorption of "kerosene" vapors on soils. Journal of Contaminant Hydrology, 4(4), 347-358. 